(Technical Association of the Pulp and Paper Industry, New York) methods.

The mere exposure of paper to 'Gammexane' smoke brought about a substantial decrease in its tensile strength and folding endurance-as much as 53.7 and 71.5 per cent respectively in one instance. Papers exposed to 'Ganmexane' and then submitted to accelerated ageing turned slightly yellow, and there was a complete loss of folding endurance in nearly all cases. All-rag hand-made paper of an extremely durable quality used for the repair of old manuscripts had a normal folding endurance of 4,164; but on exposure to 'Gammexane' smoke the retention of folding endurance was 28.5 per cent only, while on accelerated ageing the retention of folding endurance further decreased to zero.

The data obtained conclusively prove that treatment with the No. 2 'Gammexane' smoke generator is definitely injurious to paper records of all kinds and affects their durability as badly as acidic gases ${ }^{2}$. As the water through which the smoke had been bubbled was found to be distinctly acidic, it is almost certain that at least a part of the embrittling effect produced on paper ${ }^{3}$ is due to the smoke-generating materials rather than to the 'Gammexane' itself. However, the gases obtained from the smoke generator No. 2 has a deleterious effect on paper, and it is advisable to prevent it coming into direct contact with paper records and manuscripts intended for permanent preservation.

The investigation is being followed up, and the details will be published in a subsequent issue of the Indian Archives.

Research Laboratory,

National Archives of India, New Delhi. Oct. 5.

' Weber, C. G., Shaw, M. B., and Back, E. A., U.S. Bur. Stand. J. Research, 15, No. 3, 271 (1935).

2 Jarrel, T. D., Bankins, J. M., and Veitch, F. P., Tech. Bull., No. 334 U.S. Dept. of Agric., Washington, D.C.

s Kimberly, A. E., U.S. Bur. Stand. J. Research, 8, No. 2, 159 (1932).

\section{Zoosporangia, believed to be those of Plasmodiophora brassicæ, in the Root Hairs of Non-cruciferous Plants}

IN 1936, during work on the cytology of $P$. brassicce, zoosporangia identical with those of this well-known parasite were seen by me in root hairs of grass and dock seedlings, which had appeared in a pot of soil taken from a garden in which the club root disease of the Cruciferæ was a major problem. In view of the known persistence of $P$. brassicae in soils without cruciferous crops, it was decided to attempt a crude cross-inoculation experiment using club root galls as a starting point. Suitable soil was partially sterilized by keeping it at $190^{\circ} \mathrm{F}$. for one hour. Ten six-inch pots were filled with this soil, and club root galls with unbroken surfaces, but of an age known to contain mature spore masses, were cut up and placed in five of them. Brussels sprout seedlings germinated in these pots became infected, and an examination of the root hairs of the grass Holcus lanatus grown from seed with them in the re-infected soil revealed numerous zoosporangia and some free-swimming zoospores.

Twenty of these root hairs, which were, so far as could be seen, free from external debris of any kind, were placed in three of the remaining five pots of sterile soil, in which seedlings of brussels sprout were growing. In these three pots, ten of the twelve seedlings became infected, apparently with $P$. brassicae, while in the two control pots the eight plants remained free from attack.

The root hairs were removed from the Holcus plants, after careful washing in distilled water, by sucking the end of the hair into a capillary of suitable size and gently tearing away the required portion. This was done without the aid of a micro-manipula. tion apparatus, and it is fully realized that it would have been preferable to transfer zoosporangia or zoospores alone. This was, however, not possible. The cycle of events in zoospore formation in root hairs appears to be identical, up to the point at which zoospore formation begins, with the normal cycle in cruciferous roots. The somatic mitoses, transitional phase and reduction division were all seen and were similar to those described for Spongospora subterranea by Horne ${ }^{1}$ and for Sorosphora veronicce by Webb'.

In July 1948 similar zoosporangia were seen by me in two root hairs of 'Auchineruive Climax' strawberry from Botley, Hampshire. Subsequent inquiry re. vealed that club root had been troublesome in the immediate vicinity.

Plasmodiophora brassicce has been suspected of in. fecting plants other than the Cruciferæ on several occasions in the past, notably by Marchand ${ }^{3}$ in 1910. The hypertrophy described in these accounts of the disease is now usually ascribed to nematodes, and reports of the presence of the Plasmodiophora are treated with great reserve. Marchand ${ }^{3}$ saw what he believed to be Plasmodiophora in melon, celery and "oseille-epinard", which latter is believed to be a dock, $R$. patientia; but the spore diameter in melon was twice that of $P$. brassicce in crucifers, and the identity of the parasite is thus open to doubt.

In view of the present methods of control of club root, it is highly desirable that the identity of the zoosporangia I have seen, and the specificity of $P$. brassicae, should be established by cross-inoculation experiments using all possible precautions to ensure sterility.

East Malling Research Station,

PhIMIP C. R. Webi

Nr. Maidstone, Kent. Oct. 12.

${ }^{1}$ Horne, A. S., Ann. Bot., 42, 199 (1930).

${ }^{2}$ Webb, P. C. R., Ann. Bot., 49, 41 (1935).

${ }^{3}$ Marchand, E. F. I., C.R. Acad. Sei., Paris, 150, 1349 (1910).

\section{Multiplication of Coliphage at High Concentration}

THE 'single-step' method devised by Ellis and Delbrück ${ }^{1}$ has proved of immense value in the hands of a number of workers in studying the multiplication of various bacteriophages; but it was devised specifically to investigate the behaviour of bacteria and adsorbed phage at high dilution, and gives no direct information about the more complex situation normally occurring, when phage released by lysis of one bacterium can interact further with other bacteria. Since this information was necessary for a line of investigation we are pursuing, and since, moreover, it might prove of more general interest, we have devised the method described below.

Escherichia coli, strain $B$, is grown in a medium consisting of 2 per cent Bacto Tryptose, $0 \cdot 2$ per cent glucose and 0.5 per cent sodium chloride for $2 \frac{1}{2}$ hours at $37^{\circ} \mathrm{C}$., by which time the viable count is $50-70$ 